УДК 159.923

Бідюк I. $A$.

doi: $10.32620 / g c h .2018 .2 .13$

\title{
ОСОБЛИВОСТІ ОСОБИСТОСТІ МАЙБУТНЬОГО ФАХІВЦЯ АЕРОКОСМІЧНОЇ ГАЛУЗІ
}

У статті розглянуто проблему розвитку особистості та ї̈ професійних якостей. Відзначено основні ключові моменти становлення професіоналізму особистості, iї конкурентністьу сучасних суспільних умовах. Показано особистісні характеристики фахівців аерокосмічної галузі на прикладі студентів закладу вищої технічної освіти. Створено особистісний профіль якостей, щуо впливають на професійний розвиток фахівия. Охоплено питання впливу статеворольових особливостей на прояв професійних рис особистості.

Ключові слова: професійні якості, особистість, самосвідомість, самовизначення, професійно важливі якості.

The article considers the problem of formation and development of professional qualities of the individual. The influence of gender-specific personality characteristics on the manifestation of personal qualities of a modern aerospace specialistisnoted. Practical significancec on sistsinbuilding a professional personality profile and identifying importan tproperties for the emergence of the personality of a modern specialist. General characteristics of opinions of scientists about professional features of a personality aregiven.

Keywords: professional qualities, personality, self-awareness, self-determination, professionally important qualities.

Статья рассматривает проблему становления и развития профессиональных качеств личности. Отмечается влияние полоролевых особенностей личности на проявление личностных качеств современного спеииалиста аэрокосмической области. Практическое значение заключается в построении профессионального профиля личности и определении важних свойств для становлення личности современного специалиста. Предоставлена общая характеристика мнений ученых о профессиональных особенностях личности.

Ключевые слова: профессиональные качества, личность, самосознание, самоопределение, профессионально важные качества.

Зміни в системі освіти відповідно до європейських стандартів вимагають від учасниківпедагогічного процесу (педагогів, учнів, студентів) особливо високого рівня подання професійної, навчальної інформації викладачами (учителями) та сприйняття йзасвоєння цієї інформації студентами (школярами). У межах нових стандартів освіти особливої ваги набуває діяльність педагога: уміння не тільки в доступній для учня, слухача, студента формі подати важливі знання, пізнавальну інформацію, але й сформувати вміння працювати 3 цією інформацією, використовувати іiі, виокремлювати важливе та значне з-поміж іншого.

В історії розвитку педагогіки існували різні підходи до об'єктай суб'єкта процесу навчання й виховання та до учасників педагогічного процесу. У педагогічній літературі педагогічний процес розглядають як взаємодію педагога й учня (студента) 
3 метою формування чи розвитку знань, умінь, якостей чи навичок (навчальних, професійних, пізнавальних та ін.). Довгий час у педагогіці центром навчального процесу був педагог, який передає дітям знання, що формують уміння, навички для подальшого життя.

У 60-70 pp. ХХ ст. психологічні теорії внесли свої корективи не тільки в педагогічну науку, але й у практику. Завдяки особистісно-орієнтованому підходу учень (студент) стає суб'єктом, а не об'єктом педагогічного процесу, зі своїми потребами й інтересами, своїми поглядами на світ. Вплив педагога на становлення особистості школяра (студента) визначається його власними професійними знаннями, уміннями й, особливо, особистісними якостями.

Сучасні суспільні процеси вимагають особливих і більш глибоких знань не тільки в суто предметному напрямку, але також у суспільно-історичному, не тільки професійного характеру, але й, особливо, педагогічного. У професійній діяльності особистість використовує професійно важливі здібності, які забезпечують ефективність, якість і надійність цієї діяльності. Професійно важливими якостями можуть бути властивості нервової системи, особливості психічних процесів, особистісні характеристики, спрямованість, знання й переконання $[1 ; 2 ; 3]$.

Професійний, духовний розвиток особистості залежить від зовнішніх обставин, середовища й інтеріоризації зовнішньої інформації, отриманої в межах професійної діяльності та взаємодії.

Підгрунтям професійних здібностей $є$ властивості психічних процесів (сприйняття, пам'ять, увага, мислення, уява) і психомоторні функції (координація рухів, сенсомоторна координація). Професійно важливі якості залежать від специфіки професійної діяльності. Наприклад, для інженерів професійно важливими якостями $є$ соціальна активність, розвинуте технічне, творче мислення, здатність самостійно ухвалювати рішення в нестандартних ситуаціях, комунікативні здібності [4].

Становлення професіоналізму людини відбувається за дії двох груп факторів: об'єктивних і суб'єктивних. Об'єктивні - норми, вимоги, обмеження обраної професії; наявність визначених властивостей і особливостей (професійні знання й навички, професійно значні якості). Суб'єктивні - можливості (задатки), здібності, мотиви й рівень домагань, самооцінка, психологічний захист від помилок і невдач.

Психологічним підгрунтям будь-яких освітніх проектів i програм розвитку конкурентної особистості $€$ принцип саморозвитку, що інтегрується фундаментальними принципами розвитку особистості й культурно-історичної теорії формування психіки та свідомості. Розвиток особистості, пї професійних якостей i характеристик пов'язаний із розвитком самосвідомості, а саме уявлення особистості про себе, усвідомлення своїх фізичних, інтелектуальних і інших якостей, оцінювання цих якостей.

Самоусвідомлення має структуру, до складу якої входять такі компоненти: когнітивний, афективний, поведінковий, які визначають самопізнання, саморегуляцію й ставлення фахівця до своїх професійних та особистісних властивостей, якостей та ін. Професійне самоусвідомлення характеризується й залежить від багатогранності ситуацій, які потребують від людини вміння координувати свої дії 3 діями інших 
людей.

Усвідомлення людиною своїх потенційних можливостей, перспектив професійного й особистісного зростання спрямовує їі на постійне експериментування, креативність, пошук; можливість мати свободу вибору й відповідальність за ситуацію, ухвалене рішення, результат цього рішення. Професійний розвиток особистості може відбутися в тому випадку, коли людина усвідомлює свою участь i відповідальність за все, що відбувається.

Особистість розвивається й формується в системі суспільних відносин залежно від умов життя, діяльності, у процесі спілкування. Будь-яка сфера життєдіяльності людини ставить перед нею особливі вимоги до особистісних якостей. У психології існує велика кількість теорій (А. Маслоу, 3. Фрейд, А.М. Леонтьєв, К. Роджерс та ін.) особистості, що розглядають структурні компоненти, характеристики особистості, описують особливості розвитку й становлення людини в особистісному й професійному житті.

I.А. Зязюн у своїй статті «Філософія професійного розвитку людини» звертає увагу на гармонійність загального й професійного розвитку особистості й безперервність цих процесів. Професійне вдосконалення особистості відбувається в умовах «усвідомлення i прийняття учасниками педагогічного процесу системи цінностей у підготовці спеціаліста; розробка критеріїв особистості професіонала у відповідності знань, умінь і властивостей особистості вимогам життя, професійної діяльності; забезпечення повноти i неперервності у розвитку особистості; акцентування уваги на саморозвиткові особистості, iз урахуванням іiі вікових $\mathrm{i}$ соціальних особливостей» [5, с. 23].

Професійні якості залежать від соціальних процесів, явищ, індивідуальних особливостей особистості фахівця, структурних характеристик особистості, пізнавальних процесів та ін.

Студенти, що навчаються в аерокосмічному 3ВО, незалежно від напрямку підготовки, мають подібні риси особистості. Наявні відмінності говорять про специфіку (психологічний клімат) факультету, вимоги до здібностей i вмінь майбутніх фахівців, ставлення викладачів до формування знань і вмінь студентів.

Індивід вступив до ЗВТО вже 3 окремими сформованими рисами характеру; навчання у вищій школі потребує більш досконалого формування тих чи тих, властивих для певних професій, якостей і рис, відбувається процес самовиховання, який залежить не тільки від соціально-психологічних особливостей студентського оточення, але й від соціальних, економічних, політичних процесів суспільства й особливо від утвореного спеціального психолого-педагогічного навчального середовища.

Відповідно студенти аерокосмічного ЗВТО за роки навчання набувають схожих структурних особливостей і характеристик особистості. Іншими словами, студенти до 4 курсу отримують і формують у собі ті риси, які зможуть потім використати в подальшому суспільному житті, а також ті, що будуть корисні в професійному житті й зростанні.

Незначні розбіжностісеред факультетів наявні (рис. 1) у факторах A, B, F, L, O, 
Q2.

Фактор А орієнтований на визначення рівня спілкування в малих групах i здатностей установлювати безпосередні, міжособистісні контакти. Високий результат говорить, що студенти аерокосмічного ЗВТО вирізняються відкритістю й легкістю в установленні міжособистісних контактів, легко пристосовуються до умов навколишнього середовища та до їхніх змін, проявляють увагу до людини, що перебуває поряд.

Профіль особистості

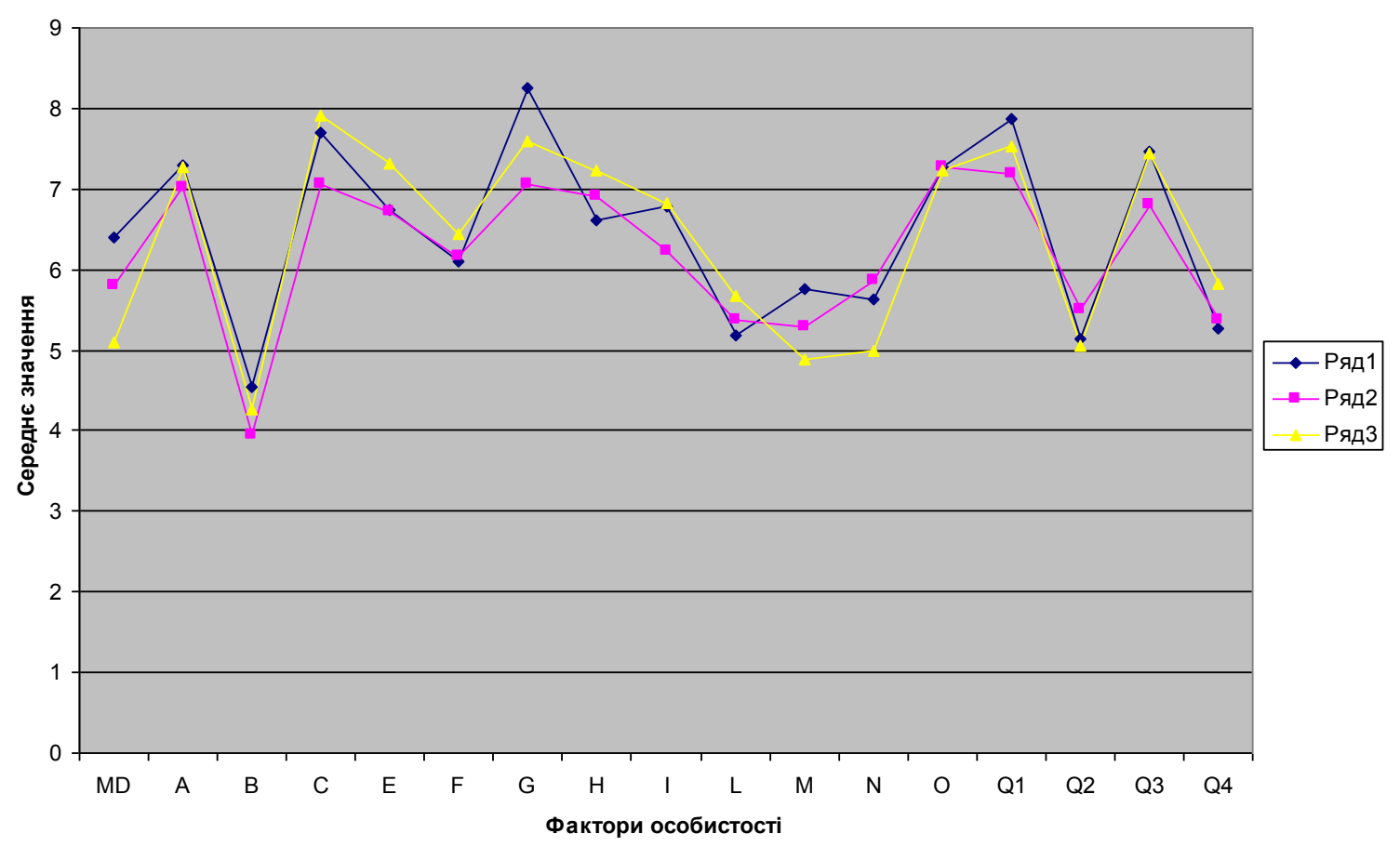

Примітка: ряд 1 - ф-т №3(системи управління літальними апаратами), ряд 2 - ф-т №1 (літакобудівний), ряд 3 - ф-т №2 (авіаційних двигунів).

Рис.1. Профіль особистості студентів аерокосмічного ЗВТО

Фактор В інтерпретується як фактор інтелекту, визначає його рівень, орієнтований на вимірювання оперативності мислення й загального рівня вербальної культури й ерудиції. Студенти відрізняються розвинутим абстрактним мисленням, швидкістю навченості, оперативністю.

Фактор F орієнтований на вимірювання емоційної насиченості й динамічності в процесах спілкування. Характеризується життєрадісним ставленням до навколишнього, емоційною яскравістю в стосунках між людьми, динамічністю спілкування й емоційним значенням соціальних контактів.

Фактор L відображає емоційне ставлення до людей. Цей фактор говорить, що студенти вирізняються обережністю, схильністю перекладати відповідальність за помилки на інших. 
Фактор О є характеристикою тривожного стану особистості. Високі показники говорять, що в студентів механічних спеціальностей виникають внутрішні суперечності, вони тяжко переносять невдачі й труднощі, чутливо ставляться до своїх успіхів і переживань.

Фактор Q2 характеризує окремий соціальний конформізм особистості. Дані можна схарактеризувати як залежність студентів у період навчання у ЗВТО від вимог i поглядів своїх одногрупників. Поступово здатність слідувати у своїй поведінці бажанням іншої людини чи групи людей перетворюється на самостійність, бажання мати власну думку, самостійність і незалежність.

Студенти літакобудівного факультету й факультету авіаційних двигунів у факторах G, H, I, L, M, N виявляють окрему пластичність у цих особистісних характеристиках та їх взаємозв'язку. Суттєва різниця існує між факультетами у факторі G. Цей фактор характеризує особливості емоційно-вольової сфери й особливості регуляції соціальної поведінки. Психологи пояснюють цей фактор як фактор наявності високого чи низького Супер-Его людини.

У цьому випадку можна вважати, що студенти спеціальності «Систем управління літальними апаратами» у своїй поведінці виявляють високі «амбіційні» вимоги стосовно свого професійного й особистісного визначення чи становлення. Але така характеристика не завжди пов'язана 3 високим інтелектуальним потенціалом студента, вона може мати мотиваційний характер. Вимоги до абсолютної та якісної успішності на факультеті призводять до механічного вивчення (заучування) навчального матеріалу без його розуміння, це надає можливість отримати відмінну оцінку, але, на жаль, не призводить до розвитку професійних інтелектуальних умінь і навичок.

У соціальних стосунках проявляють стабільність, цілеспрямованість, урівноваженість, імпульсивність, гнучкість щодо соціальних норм поведінки чи життя, підгрунтям ставлень до соціальних норм і правил уважають досягнення своїх бажань та їхнє задоволення.

Шкалу MD психологи визначають як фактор правдивості результатів опитувальника. Ми вважаємо, що цей фактор краще визначати й характеризувати як шкалу самооцінки, за допомогою якої можна іï описати. Отримані результати дають підставу говорити, що студенти факультету систем управління літальними апаратами оцінюють свої якості й можливості більш позитивно, ніж студенти літакобудівного факультету та факультету авіаційних двигунів, це визначає як їхню адекватну самооцінку, так і схильність до їі завищення.

Результати, зображені на рис. 1, говорять про вплив атмосфери ЗВТО чи факультету, середовища, у якому навчаються (чи перебувають) студенти, на формування й прояв тих чи тих особистісних рис. При цьому ті чи ті риси, що виявляються в індивідуума під час навчання у ЗВТО, можна визначити як професійні, що не залежать від статі. Тобто припускаємо, що це риси, притаманні саме інженерам аерокосмічної галузі, без впливу статевих особливостей.

Професійні якості й особливості особистості сучасних фахівців залежать від багатьох умов і факторів, що проявляються в суспільних явищах і процесах, створенні 
педагогічного середовища, спрямованого на формування професійних якостей, у вимогах до складових особистості сучасного фахівця, до їх професійних здібностей, показників, інтегральних характеристик.

Структурні характеристики особистості молодого фахівця залежать і від рівня розвитку професійних інтелектуальних якостей, рівня розвитку складових професійного інтелекту. Зв'язок між професійними якостями (сприйняття інформації, уміння працювати 3 отриманими даними для розв'язання виробничих завдань, ухвалення ефективного рішення та ін.) i характеристиками особистості (спрямованість, компетентність, емоційна й поведінкова гнучкість, інтелектуальна гнучкість) і визначає образ фахівця.

Структура особистості майбутнього фахівця (на прикладі студентів аерокосмічного ЗВТО) визначена проявом характеристик, що показують особливості цієї особистості. У соціальних стосунках виявляють стабільність, цілеспрямованість, урівноваженість, імпульсивність, гнучкість щодо соціальних норм поведінки.

У спілкуванні встановлюють безпосередність і відкритість, досить легко, безболісно пристосовуються до умов навколишнього середовища та до змін уцих умовах. Досягаючи встановленої мети у своїй поведінці, виявляють високі «амбіційні» вимоги щодо професійного й особистісного визначення чи становлення. Поряд із амбіційністю в студентів виникають внутрішні труднощі, вони важко переживають невдачі й труднощі; уважно ставляться до своїх успіхів і переживань.

Відкритість у соціальних стосунках може мати зовнішні вияви, у дійсності студенти відрізняються обережністю, схильністю перекладати відповідальність за помилки на інших. Відношення всередині групи характеризуються життєрадісним ставленням до навколишнього, емоційністю та яскравістю. Структурні складові особистості залежать від статеворольової сфери.

У цілому студенти мають почуття реальності, самостійність мислення, добре розвинене почуття мови, індуктивне мовне мислення, чітке вираження словесних значень, здатність комбінувати інформацію, гнучкість і пластичність мислення, розуміння відношення між предметами та їхніми функціями, уміння знаходити правильне рішення. Уміють грамотно й грунтовно формулювати свої думки, упорядковувати інформацію, яку отримують чи використовують.

Гендерні особливості професійно важливих інтелектуальних здібностей виявляються в студентів на соціогенному рівні. У період професійного й особистісного становлення студентів відсутня стабільність в уявних $\mathrm{i}$ дійсних складових структури особистості.

\section{Література:}

1. Шадриков В.Д. Психологический анализ деятельности как системы // Психологический журнал. 1980. Т. 1. № 3. С. 33-46.

2. Шадриков В. Д. О структуре познавательных способностей // Психологический журнал. 1985. T. 6. № 3. С. 38-46.

3. Шадриков В.Д. Диагностика способностей и личностных черт учащихся в учебной деятельности. Саратов: Изд-во Сарат. ун-та. 1989. 234 с. 
4. Моляко В. А.Творческая конструктология (пролегомены). Київ : «Освита Украины», 2007. $388 \mathrm{c}$.

5. Проблеми та перспективи формування національної гуманітарно-технічної еліти : зб. наук. праць; за ред. Л. П. Товажнянського та О. Г. Романовського. Національний технічний університет «ХПІ». Харків, 2004. Випуск 5(9). С. 51-63.

6. Батаршев А. В., Алексеева И. Ю., Майорова Е. В. Диагностика профессионально важных качеств. СПб. : Питер, 2007. 192 с.

7. Митина Л. М. Психология развития конкурентоспособной личности. М., Воронеж : НПО «МОДЭК», 2003. $400 \mathrm{c}$.

\section{Inna Bidyuk}

\section{PERSONALITY FEATURES OF FUTURE SPECIALIST IN AEROSPACE SPHERE}

Modern social processes require special and more profound knowledge not only in a purely subject area, but also in the socio-historical sphere. In the professional activity, the person uses professionally important abilities that ensure effectiveness, quality and reliability of this activity.

Professional and spiritual development of the individual depends on external circumstances, the environment and internalization of external information obtained within professional activity and interaction.

The basis of professional abilities is the properties of mental processes (perception, memory, attention, thinking and imagination) and psychomotor functions (coordination of movements and sensorimotor coordination). Professionally important qualities depend on the specifics of professional activity.

The formation of human professionalism takes place under the influence of two groups of factors: objective and subjective. Objective ones include norms, requirements, restrictions of the chosen profession; the presence of certain properties and features (professional knowledge and skills, professionally significant qualities, etc.). Subjective factors consist of possibilities (inclinations), abilities, motives and level of aspirations, selfesteem, psychological protection against mistakes and failures.

Personality development, as well as its professional qualities and characteristics is associated with the development of self-awareness, namely: self-conception, awareness of physical, intellectual and other qualities, and evaluation of these qualities.

Self-awareness has a structure that includes the following components: cognitive, affective, behavioral ones, which determine self-cognition, self-regulation and the attitude of a specialist to their professional and personal qualities, etc. Professional self-awareness is characterized and depends on the multi-sidedness of situations that require a person's ability to coordinate their actions with the actions of other people.

Professional development of the person can occur in case a person is aware of his participation and responsibility for everything that is happening. 
Professional qualities and features of the personality of modern specialists depend on many conditions and factors that are manifested in social phenomena and processes, the creation of a pedagogical environment aimed at the formation of professional qualities, in the requirements for the components of the personality of a modern specialist, to their professional abilities, indicators and integral characteristics.

Structural characteristics of the personality of a young specialist depend on the level of development of professional intellectual qualities, the level of development of components of professional intelligence. The connection between professional qualities (perception of information, ability to work with the received data for the decision of production tasks, acceptance of an effective decision, etc.), and personal characteristics (orientation, competence, emotional and behavioral flexibility, intellectual flexibility) determines the image of a specialist.

The structure of the personality of a future specialist (for example, students of aerospace VTNZ) is determined by the characteristics that show the peculiarities of this individual. In social relations we can define stability, purposefulness, balance, impulsivity and flexibility concerning social norms of behavior.

Бідюк Інна Аркадіївна - кандидат психологічних наук, доцент, доцент кафедри психології гуманітарного факультету Національного аерокосмічного університету ім. М.Є. Жуковського «XАI».

Надійшла до редакції 19.06.2018. Розглянута на редколегії 25.06.2018.

\section{Рецензенти:}

Доктор філософських наук, завідувач кафедри філософії Національного аерокосмічного університету ім. М.С. Жуковського «ХАІ» Чернієнко В.О.

Кандидат політичних наук, доцент, доцент кафедри права Національного аерокосмічного університету ім. М.С. Жуковського «ХАІ» Ковальова I.I. 